\title{
The Effect of Methyl Glyoxal on Cell Division and the Synthesis of Protein and DNA in Synchronous and Asynchronous Cultures of Escherichia coli $\mathrm{B} / \mathrm{r}$
}

\author{
By HADRIAN N. A. FRAVAL AND DAVID C. H. MCBRIEN* \\ Biochemistry Department, Brunel University, Uxbridge, Middlesex UB8 $3 P H$
}

(Received 30 May 1979; revised 6 September 1979)

\begin{abstract}
Methyl glyoxal inhibits the growth of Escherichia coli in synchronous and asynchronous culture. The inhibition of growth is accompanied by immediate inhibition of protein synthesis and of the initiation of replication of DNA. When methyl glyoxal is added after initiation of a round of replication the elongation of new DNA chains is not inhibited. Cell division is inhibited if methyl glyoxal is added up to about $22 \mathrm{~min}$ prior to division. These results support the view that the primary effect of methyl glyoxal is on protein synthesis.
\end{abstract}

\section{INTRODUCTION}

The simplest $\alpha$-ketoaldehyde, methyl glyoxal $\left(\mathrm{CH}_{3} \mathrm{COCHO}\right)$, is a natural product of the metabolism of Escherichia coli (Cooper \& Anderson, 1970) and of some other bacteria (Cooper, 1974) although it has been known for some time that methyl glyoxal and other $\alpha$-ketoaldehydes can be cytostatic or cytotoxic (Ackerman et al., 1974; Egyud \& SzentGyorgyi, 1966 b; Gudas \& Pardee, 1974). Indeed, E. coli can be induced by mutation (Freedberg et al., 1971; Zwaig \& Diegnez, 1970) or by manipulation of the growth conditions (Ackerman et al., 1974) to produce lethal concentrations of methyl glyoxal. The biochemical mechanism of methyl glyoxal inhibition has not been fully elucidated. Egyud \& SzentGyorgyi (1966a) and Otsuka \& Egyud (1968) have reported that protein synthesis in a variety of different prokaryotic and eukaryotic cells is the primary target of methyl glyoxal inhibition and that synthesis of DNA and RNA is only weakly inhibited. However, Krymkiewicz et al. (1971) have reported that in bacteria the synthesis of protein, DNA and RNA are all strongly inhibited by methyl glyoxal.

We have undertaken an investigation into the effect of methyl glyoxal on macromolecular synthesis in $E$. coli $\mathrm{B} / \mathrm{r}$ and present here results which indicate that both DNA and protein synthesis are strongly inhibited. To identify the primary target of methyl glyoxal action we have investigated its effect on the rate of DNA synthesis, protein synthesis and cell division in synchronously growing $E$. coli $\mathrm{B} / \mathrm{r}$.

\section{METHODS}

Growth of organisms. Escherichia coli $\mathrm{B} / \mathrm{r}$ was used throughout this investigation and was obtained from the National Collection of Industrial Bacteria (NCIB 9485). Cultures were maintained on Penassay agar slopes (Difco) and subcultured for experiments into $0.1 \%(\mathrm{w} / \mathrm{v})$ glucose minimal medium (Pardee \& Prestidge, 1961). Cells were grown at $37^{\circ} \mathrm{C}$ with orbital shaking.

Cell cycle synchronization. The sucrose gradient centrifugation (size selection) technique proposed by Mitchison \& Vincent (1965) and modified by Gudas \& Pardee (1974) was used to obtain synchronous cultures of $E$. coli $\mathrm{B} / \mathrm{r}$. The cultures obtained had a doubling time of $45 \mathrm{~min}$ and showed stepwise increases in cell number and in the rate of DNA synthesis. 
Determination of cell number. Cell counts were obtained with a model ZF Coulter counter fitted with a $30 \mu \mathrm{m}$ orifice. Samples of $0 \cdot 1 \mathrm{ml}$ were removed from a synchronously growing culture and added to $0 \cdot 1 \mathrm{ml}$ of cold $10 \%(\mathrm{v} / \mathrm{v})$ formaldehyde. Cells stored in this way were counted within $6 \mathrm{~h}$ of sampling and counts showed a sample variation of $\pm 5 \%$. All solutions were routinely filtered through Millipore filters $(0 \cdot 22 \mu \mathrm{m}$ pore size) prior to experiments, to minimize counting error.

Estimation of the rate of $D N A, R N A$ and protein synthesis. The rate of incorporation of radioactive precursors into DNA, RNA or protein was determined by removing $0.4 \mathrm{ml}$ of culture at regular intervals and adding it to $0.1 \mathrm{ml}$ of $0.1 \%(\mathrm{w} / \mathrm{v})$ glucose minimal medium containing the required radioactive precursor: $\left[{ }^{3} \mathrm{H}\right]$ thymidine $\left[0 \cdot 4 \mu \mathrm{Ci}, 5 \mathrm{Ci} \mathrm{mmol}^{-1}\left(185 \mathrm{GBq} \mathrm{mmol}^{-1}\right)\right],\left[{ }^{3} \mathrm{H}\right]$ leucine $\left[2 \mu \mathrm{Ci}, 1 \mathrm{Ci} \mathrm{mmol}^{-1}\left(37 \mathrm{GBq} \mathrm{mmol}^{-1}\right)\right]$ or $\left[{ }^{3} \mathrm{H}\right]$ uracil $\left[0.4 \mu \mathrm{Ci}, 5 \mathrm{Ci} \mathrm{mmol}^{-1}\left(185 \mathrm{GBq} \mathrm{mmol}^{-1}\right)\right]$. The incorporation was stopped after 3 or $3.5 \mathrm{~min}$ by the addition of $0.5 \mathrm{ml}$ ice-cold $10 \%(\mathrm{w} / \mathrm{v})$ trichloroacetic acid containing $0.25 \mathrm{mg}$ unlabelled precursor. Samples were kept on ice until the end of a run; then, after filtration on to Whatman $2.5 \mathrm{~cm} \mathrm{GF} / \mathrm{C}$ glass fibre filters, the radioactivity was determined by liquid scintillation counting.

Methyl glyoxal. Methyl glyoxal [Sigma Grade III, as $40 \%(\mathrm{w} / \mathrm{v})$ aqueous solution] was purified by direct steam distillation and its concentration was determined by the method of Sawicki et al. (1961). Unless stated otherwise, it was added to cultures to give a final concentration of $0.25 \mathrm{~mm}$.

\section{RESULTS}

\section{The effects of methyl glyoxal}

Effect on growth. When methyl glyoxal was introduced into asynchronous cultures of E. coli $\mathrm{B} / \mathrm{r}$ growing exponentially on glucose minimal medium, inhibition of growth was observed, the extent of inhibition depending both on the cell density at the time of addition and on the concentration of methyl glyoxal in the culture. Methyl glyoxal at $0.25 \mathrm{~mm}$ completely inhibited the growth of a culture containing $3.7 \times 10^{6}$ cells ml ${ }^{-1}$ but $0.5 \mathrm{~mm}$ was required for the same effect in a culture containing $5 \times 10^{7}$ cells ml ${ }^{-1}$. Moreover, $0.5 \mathrm{~mm}-$ methyl glyoxal did not elicit complete inhibition of growth in a culture containing $3.4 \times$ $10^{8}$ cells $\mathrm{ml}^{-1}$.

Effects on macromolecular synthesis. Figure 1 shows the effects on the rates of synthesis of protein, DNA and RNA of the inclusion of methyl glyoxal in an asynchronous culture of E. coli $\mathrm{B} / \mathrm{r}\left(3 \times 10^{6}\right.$ cells $\left.\mathrm{ml}^{-1}\right)$ growing exponentially in glucose minimal medium. In the case of protein synthesis (Fig. 1a), the addition of methyl glyoxal was followed by a large immediate decrease in the rate of synthesis. The rate continued to fall throughout the experiment; by $60 \mathrm{~min}$ after addition, the rate was $10 \%$ of that in the control. In samples from the same culture, the rate of DNA synthesis also fell immediately after the addition of methyl glyoxal (Fig. 1b). However, the fall in the rate of DNA synthesis was not as large as that of protein synthesis. The decreased rate of synthesis remained nearly constant throughout the remainder of the experiment and was $26 \%$ of the control rate $60 \mathrm{~min}$ after addition of the inhibitor. In a similar experiment, the rate of RNA synthesis was not immediately affected by the addition of methyl glyoxal (Fig. $1 c$ ), remaining similar to that of the control culture for about $20 \mathrm{~min}$ after addition of the inhibitor. However, by $60 \mathrm{~min}$ after addition the rate of RNA synthesis had dropped to $68 \%$ of the control value. These results suggest that protein synthesis and DNA synthesis are strongly inhibited by methyl glyoxal whereas the inhibition of RNA synthesis is probably a secondary effect.

Effect on DNA synthesis in synchronous cultures. To investigate whether the rate of DNA

Fig. 1. Effects of methyl glyoxal on macromolecular synthesis: (a) protein; (b) DNA; (c) RNA. Methyl glyoxal $(0.25 \mathrm{~mm})$ was added to cultures $\left(3 \times 10^{6}\right.$ cells $\left.\mathrm{ml}^{-1}\right)$ at the times indicated by the arrows. Each point indicates the rate of incorporation of labelled precursor measured over a period of 3 or $3.5 \mathrm{~min}$ immediately after the sample was removed from the culture. Control cultures $(\boldsymbol{O})$, treated cultures $(\bigcirc, \triangle, \square)$.

Fig. 2. Effect of methyl glyoxal on the rate of DNA synthesis in synchronized cultures. Methyl glyoxal $(0.25 \mathrm{~mm})$ was added to cultures at the times indicated by the arrows, i.e. $(a)$ after initiation, $(b)$ early in the initiation step and $(c)$ late in the initiation step. Control cultures (O), treated cultures ( $\square$ ). 

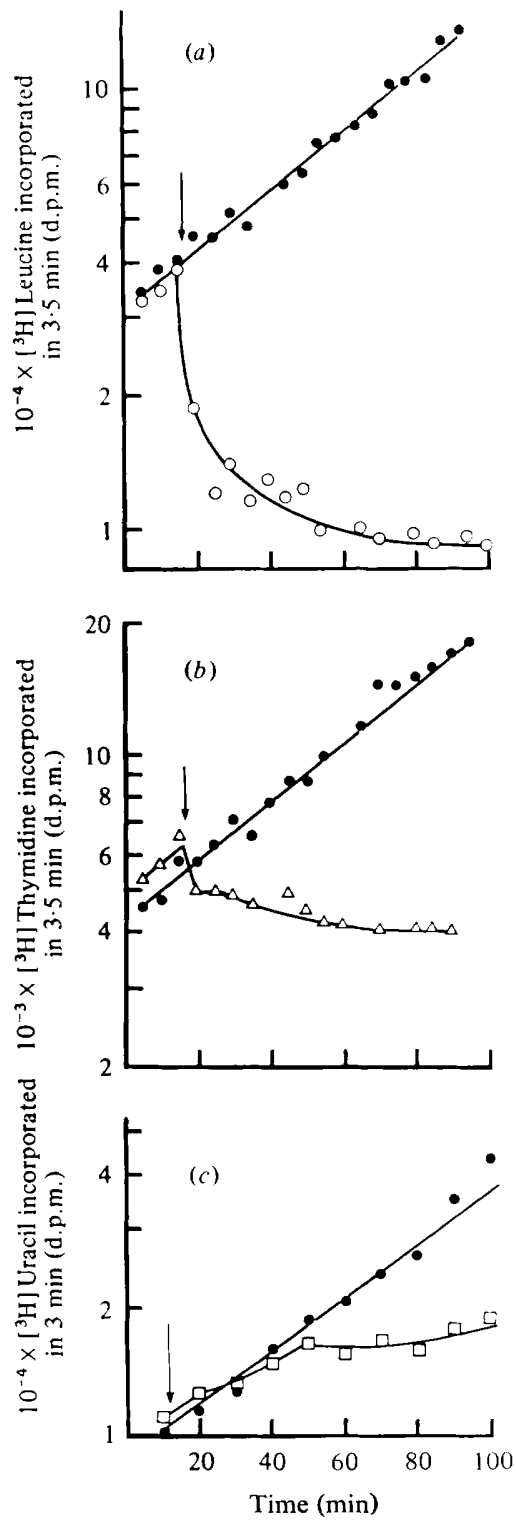

Fig. 1
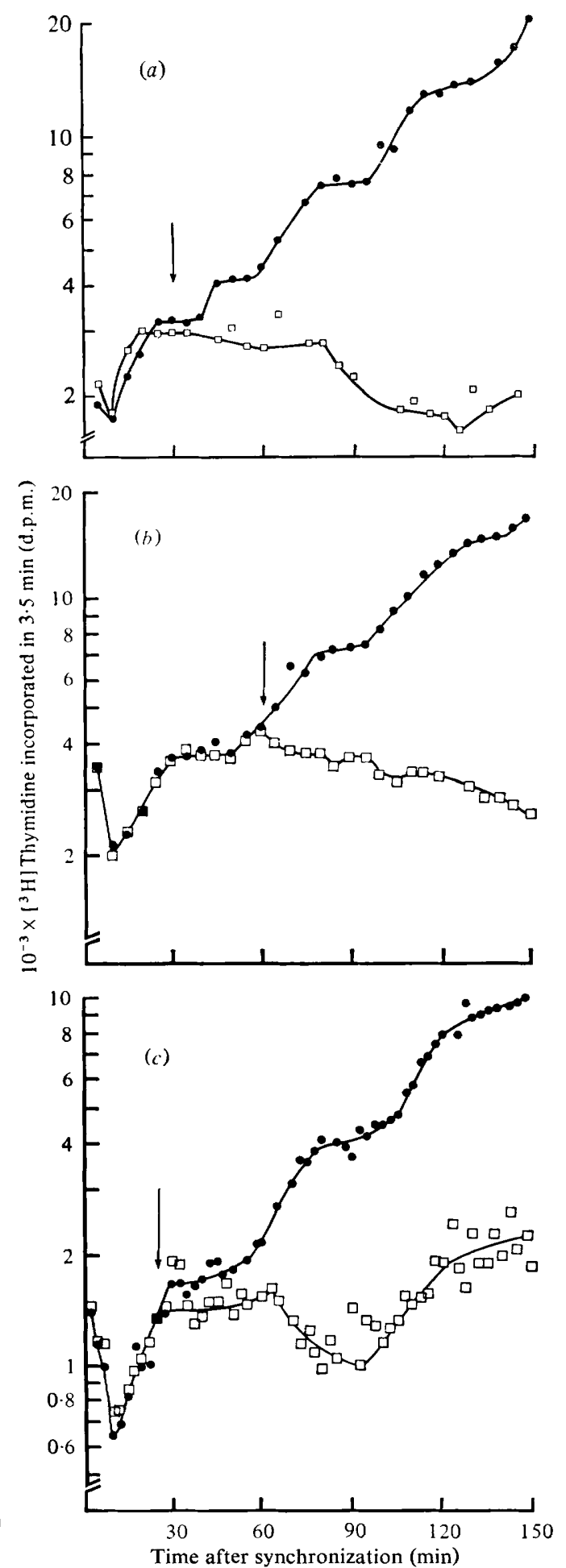

Fig. 2 


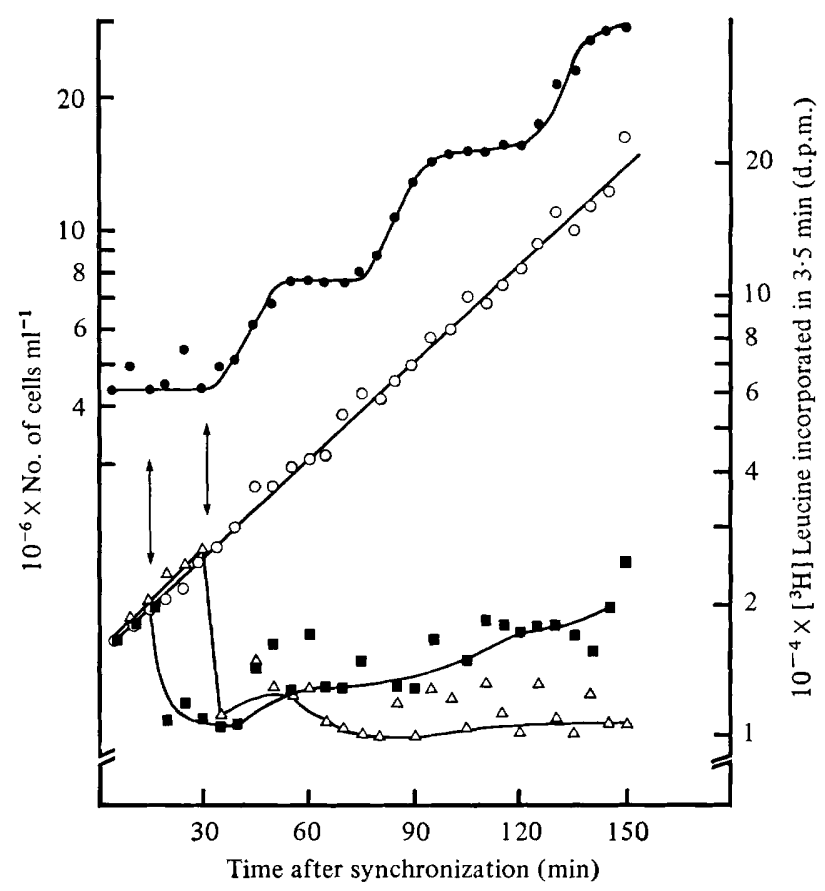

Fig. 3. Effect of methyl glyoxal on the rate of protein synthesis in synchronized cultures. Methyl glyoxal $(0.25 \mathrm{~mm})$ was added to cultures $20 \mathrm{~min}(\boldsymbol{\square})$ and $5 \mathrm{~min}(\triangle)$ prior to the beginning of a period of cell division. The cell number $(\bullet)$ and rate of protein synthesis $(O)$ in a control culture are also shown.

chain elongation was reduced after the addition of methyl glyoxal, we added methyl glyoxal at $0.25 \mathrm{~mm}$ (a concentration which completely prevented growth of a culture containing $6 \times 10^{6}$ cells $\mathrm{ml}^{-1}$ ) to a synchronous culture of $E$. coli $\mathrm{B} / \mathrm{r}$, in which all the cells had successfully initiated a round of DNA replication (Fig. $2 a$ ). There was no immediate reduction in the rate of DNA synthesis, in contrast to the observation in asynchronous cultures (Fig. $1 b$ ). However, the initiation of subsequent rounds of DNA replication was completely inhibited in the treated culture although they occurred in the control.

Effect on initiation of DNA replication. The addition of methyl glyoxal to a synchronous culture of $E$. coli $\mathrm{B} / \mathrm{r}$ about $5 \mathrm{~min}$ after the start of the initiation step resulted in a complete block in the initiation of a new round of DNA synthesis (Fig. $2 b$ ). This effect is further illustrated in Fig. 2(c) in which the majority of the cells in the culture had already initiated a round of DNA replication before the addition of methyl glyoxal. Cells which had not initiated a new round of DNA replication at the time of treatment were apparently prevented from doing so. However, the rate of DNA synthesis after the addition of methyl glyoxal did not immediately decrease but remained at the level achieved immediately prior to methyl glyoxal addition for $40 \mathrm{~min}$. Only then did the rate of DNA synthesis decrease. We interpret these observations as indicating that methyl glyoxal inhibits initiation of new rounds of DNA replication but does not affect rounds of replication already in progress. It is apparent that the rate of DNA synthesis in the culture shown in Fig. 2(c) again increased $60 \mathrm{~min}$ after methyl glyoxal addition. This is possibly a result of the activity of the glyoxalase system which metabolizes methyl glyoxal to D-lactate (Racker, 1951); a reduction in methyl glyoxal concentration would then allow initiation to take place.

Effect on protein synthesis in synchronous cultures. The change in the rate of protein synthesis after adding methyl glyoxal to a synchronously growing culture of $E$. coli $\mathrm{B} / \mathrm{r}$ $5 \mathrm{~min}$ and $20 \mathrm{~min}$ before cell division is shown in Fig. 3. In both cases the rate of protein 
synthesis immediately decreased. The inhibition of the rate of protein synthesis continued for the duration of the experiment.

Effect on cell division in synchronous cultures. Since methyl glyoxal has previously been shown to be cytostatic in bacterial cultures, we determined its effect on the ability of synchronously growing $E$. coli $\mathrm{B} / \mathrm{r}$ cells to divide. Figure 4 illustrates a series of experiments in which methyl glyoxal was added at various times prior to division. Addition 5 or $10 \mathrm{~min}$ before the first cells divided (Fig. $4 a, b$ ) did not affect the timing or extent of the subsequent cell division. Addition $12 \mathrm{~min}$ before the first cells divided (Fig. $4 \mathrm{c}$ ) permitted most of the cells to divide in the current cycle, but inhibited cells which would otherwise have divided towards the end of the division period. This inhibition could be seen approximately $22 \mathrm{~min}$ after adding methyl glyoxal, the rate of cell division becoming markedly slower although the cell number eventually approached that of the control. A similar result was obtained when methyl glyoxal was added $20 \mathrm{~min}$ before division (Fig. $4 d$ ). In this case the rate of increase in cell number was inhibited from the start of the division step but eventually cell numbers again reached the control value. In none of these experiments (Fig. $4 a$ to $d$ ) was the timing of the start of the division step affected by the addition of methyl glyoxal.

Adding methyl glyoxal 24 min before cell division was due (Fig. $4 e$ ) resulted in a delay in the onset of cell division until $45 \mathrm{~min}$ after division took place in the control. Some, but not all, cells were then able to divide. Addition of methyl glyoxal $30 \mathrm{~min}$ before division (Fig. $4 f$ ) gave a similar result to that shown in Fig. 4(e) except that even fewer cells were eventtually able to divide. None were able to divide in the step due $45 \mathrm{~min}$ after addition of methyl glyoxal (Fig. 4a).

\section{DISCUSSION}

Methyl glyoxal has an inhibitory effect on the growth rate of E. coli, the extent of inhibition being dependent on both the methyl glyoxal concentration and the cell density of the culture. Szent-Gyorgyi et al. (1967) observed that if the cell density was increased tenfold the methyl glyoxal concentration had to be increased tenfold to elicit a comparable degree of inhibition. However, our results indicate that when the cell density is increased approximately tenfold from $3.7 \times 10^{6}$ to $5 \times 10^{7}$ cells $\mathrm{ml}^{-1}$ the concentration of methyl glyoxal required for complete inhibition of growth increased only twofold, from $0.25 \mathrm{~mm}$ to $0.5 \mathrm{~mm}$. We cannot account for this discrepancy.

We observed (Fig. 1) that methyl glyoxal caused greater immediate inhibition of protein synthesis than DNA synthesis although both were strongly inhibited. These results agree with the findings of Egyud \& Szent-Gyorgyi (1966 b) and Krymkiewicz et al. (1971) insofar as they demonstrate a strong inhibition of protein synthesis by concentrations of methyl glyoxal that completely inhibit growth. However, our observation that DNA synthesis is considerably inhibited by methyl glyoxal is contrary to the findings of Egyud \& SzentGyorgyi $(1966 \mathrm{~b})$. It is important to note that in our studies we measured the rate of macromolecular synthesis at various times after treatment, whereas in previous reports (Egyud \& Szent-Gyorgyi, 1966 b; Krymkiewicz et al., 1971) only the total synthesis during a prolonged incubation was measured.

Addition of methyl glyoxal to synchronously growing cells after the initiation of a round of DNA replication had taken place did not reduce the rate of DNA chain elongation. However, adding methyl glyoxal prior to, or at the time of, initiation of DNA replication resulted in complete inhibition of the process. Thus methyl glyoxal probably selectively inhibits initiation of DNA synthesis rather than DNA synthesis per se. DNA synthesis in bacteria is not a continuous process (Helmstetter, 1968); its initiation involves the formation of a complex which requires prior protein synthesis (Lark et al., 1963; Maaløe \& Hanawalt, 1961). Once DNA replication has been initiated no further protein synthesis is required until termination of the round of replication. There are a number of possible mechanisms which could be considered to explain the effect of methyl glyoxal on initiation. A specific 

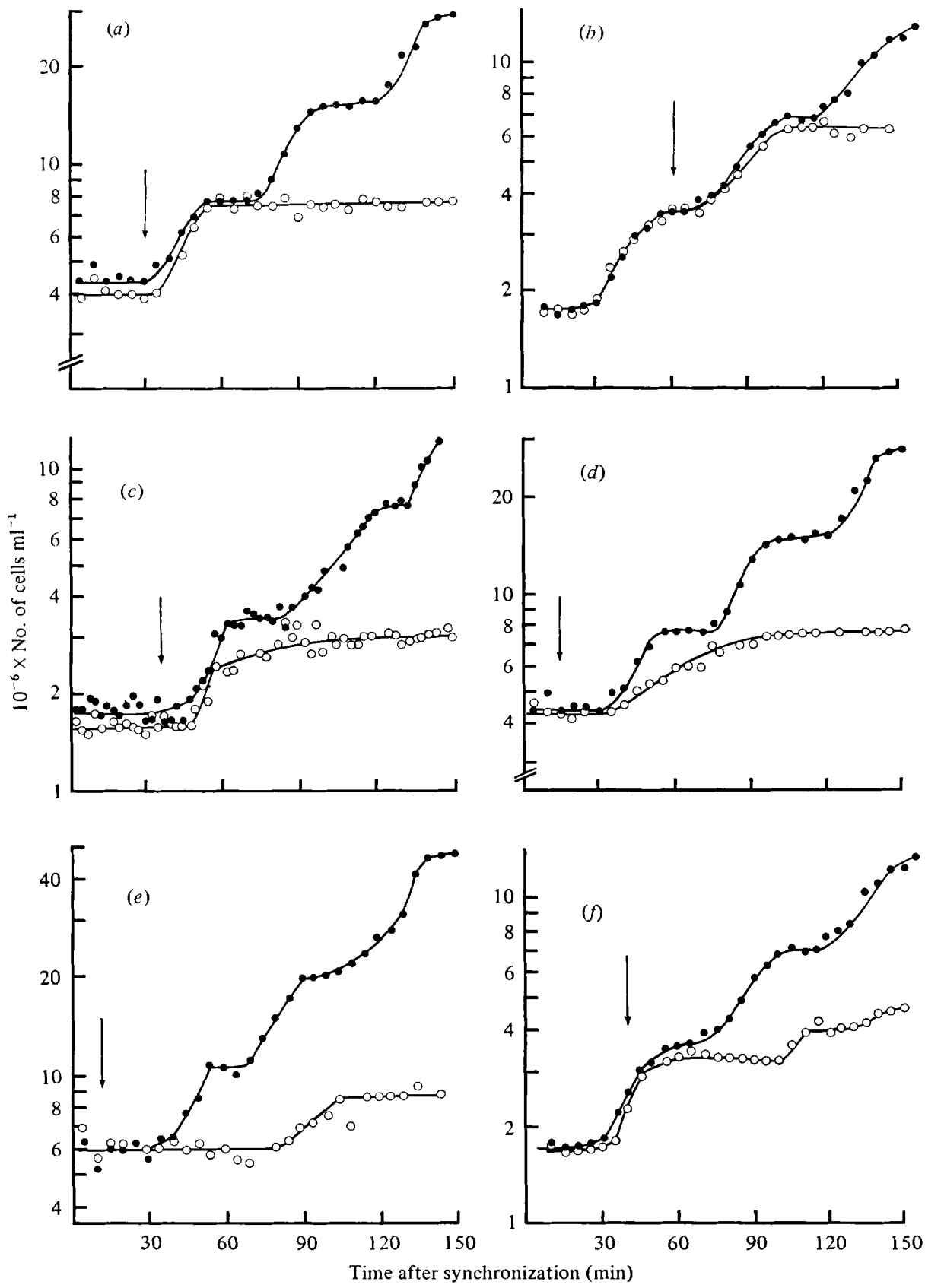

Fig. 4. Effect of methyl glyoxal on cell division in synchronized cultures. Methyl glyoxal $(0 \cdot 25 \mathrm{~mm})$ was added to cultures at the times indicated by the arrows, i.e. $(a) 5 \mathrm{~min},(b) 10 \mathrm{~min},(c) 12 \mathrm{~min}$, (d) $20 \mathrm{~min},(e) 24 \mathrm{~min}$ and $(f) 30 \mathrm{~min}$ prior to the start of cell division. Control cultures $(\bullet)$, treated cultures $(\bigcirc)$.

interaction of methyl glyoxal with the initiation complex or the reaction of methyl glyoxal with the so-called 'anti-inhibitor' proposed by Rosenberg et al. (1969) could occur. Another possibility is that the inhibition of initiation of DNA synthesis is a result of the inhibition of protein synthesis, since protein synthesis is undoubtedly required for initiation (Lark et al., 
1963; Maaløe \& Hanawalt, 1961). Indeed, it has been reported that protein synthesis is required at the time of initiation (Ward \& Glasser, 1969) or $5 \mathrm{~min}$ before initiation takes place (Lark \& Renger, 1969; Messer, 1972). The immediate inhibition of protein synthesis after addition of methyl glyoxal (Fig. 3) lends support to the proposal that the block in initiation of DNA replication is due specifically to inhibition of protein synthesis.

The effects of methyl glyoxal on cell division (Fig. 4) may also be a consequence of the inhibition of protein synthesis. Although protein, RNA and DNA synthesis are required up to $20 \mathrm{~min}$ before division, no protein, RNA or DNA synthesis is required in about the last $20 \mathrm{~min}$ of the bacterial cell cycle (Jones \& Donachie, 1973). According to the model of Jones \& Donachie (1973) a termination protein is synthesized at completion of a round of replication, about $20 \mathrm{~min}$ prior to cell division. Inhibition of protein synthesis 20 or more minutes before cell division would therefore result in a delay in the timing of cell division. We have observed that the timing of cell division was only affected when methyl glyoxal was added about 22 min before the division event. Addition more than 22 min before division either delayed it or completely prevented it taking place. Because of the approximate timings, our observations can be explained by the Jones \& Donachie (1973) model if methyl glyoxal prevents the synthesis of the termination protein. Jones \& Donachie (1973) used chloramphenicol as an inhibitor of protein synthesis in cultures which had been synchronized by a technique which permitted events which normally occur in the 20 min period between the completion of a period of chromosome replication and cell division to be largely completed during the pretreatment period during which DNA synthesis was inhibited. If methyl glyoxal had caused a total permanent inhibition of protein synthesis its presence should cause a total permanent block to cell division. The fact that we observed that division was delayed but not permanently inhibited can be explained by two observations. At the concentration of methyl glyoxal which we used, protein synthesis was not completely inhibited and thus the termination protein might still have been produced, but at a time later than usual. In addition, the bacteria contained the glyoxalase system (Racker, 1951) which metabolizes methyl glyoxal, continuously reducing its concentration. We are investigating whether chloramphenicol used in our synchronous cultures mimics the effects of methyl glyoxal on cell division but with the advantage of not being metabolically removed. We predict that it should, if, like Otsuka \& Egyud (1968), we are correct in proposing that the primary effect of methyl glyoxal is on protein synthesis.

H. N. A. Fraval gratefully acknowledges receipt of an S.R.C. studentship.

\section{REFERENCES}

Ackerman, R. S., Cozzarelli, N. R. \& Epstein, W. (1974). Accumulation of toxic concentrations of methyl glyoxal by wild-type Escherichia coli K12. Journal of Bacteriology 119, 357-362.

Cooper, R. A. (1974). Methyl glyoxal formation during glucose catabolism by Pseudomonas saccharophila. European Journal of Biochemistry 44, 81-86.

Cooper, R. A. \& Anderson, A. (1970). The formation ard catabolism of methyl glyoxal during glycolys,is in Escherichia coli. FEBS Letters 11, 273-276.

Egyud, I. G. \& Szent-Gyorgyi, A. (1966a). Cell division, SH, ketoaldehydes and cancer. Proceeding: of the National Academy of Sciences of the Uniled States of America 55, 388-393.

Egyud, L. G. \& Szent-Gyorgyi, A. (1966b). On the regulation of cell division. Proceedings of the Nationa! Academy of Sciences of the United States of America 56, 203-207.

Freedberci, W. B., Kistler, W. S. \& Lin, E. C. C.
(1971). Lethal synthesis of methyl glyoxal by Escherichia coli during unregulated glycerol metabolism. Journal of Bacteriology 108, 137144.

Gudas, L. J. \& Pardee, A. B. (1974). Deoxyribonucleic acid synthesis during the division cycle of Escherichia coli: a comparison of strains $\mathrm{B} / \mathrm{r}, \mathrm{K} 12$, 15 , and $15 \mathrm{~T}^{-}$under conditions of slow growth. Journal of Bacteriology 117, 1216-1223.

Helmstetter, C. E. (1968). Origin and sequence of chromosome replication in Escherichia coli $\mathrm{B} / \mathrm{r}$. Journal of Bacteriology 95, 1634-1642.

Jones, N. C. \& DonaChie, W. D. (1973). Chromosome replication, transcription and control of cell division in Escherichia coli. Nature New Biology 243, $100-103$.

Krymkiewicz, N., Dieguez, E., Rekarte, U. D. \& ZWAIG, N. (1971). Properties and mode of action of a bactericidal compound (=methyl glyoxal) produced by a mutant of Escherichia coli. Journal of Bacteriology 108, 1338-1347. 
LARK, K. G. \& RENGER, H. (1969). Initiation of DNA replication in Escherichia coli $15 \mathrm{~T}^{-}$: chronological dissection of three physiological processes required for initiation. Journal of Molecular Biology 42, 221-235.

LARK, K. G., RePKo, T. \& Hoffman, E. J. (1963). The effect of amino acid deprivation on subsequent DNA replication. Biochimica et biophysica acta 76, 9-24.

Maaløe, O. \& Hanawalt, P. C. (1961). Thymine deficiency and the normal DNA replication cycle. Journal of Molecular Biology 3, 144-145.

MESSER, W. (1972). Initiation of DNA replication of Escherichia coli $\mathrm{B} / \mathrm{r}$ : chronology of events and transcriptional control of initiation. Journal of Bacteriology 112, 7-12.

Mrtchison, J. J. \& Vincent, W. S. (1965). Preparation of synchronous cell cultures by sedimentation. Nature, London 205, 987-989.

Otsuka, H. \& Egyud, L. G. (1968). Locus of the inhibition of protein synthesis by aldo-ketones. Currents in Modern Biology 2, 106-110.

Pardee, A. B. \& Prestidge, L. S. (1961). The initial kinetics of enzyme induction. Biochimica et biophysica acta 49, 77-82.
RACKER, E. (1951). The mechanism of action of glyoxalase. Journal of Biological Chemistry 190, 685-696.

Rosenberg, B. H., Cavelieri, L. F. \& Ungers, G. (1969). The negative control mechanism of $E$. coli DNA replication. Proceedings of the National Academy of Sciences of the United States of America 63, 1410-1417.

Sawicki, E., Hauser, T. R., Stanley, T. W. \& ELBERT, W. (1961). The 3-methyl-2-benzothiazolone hydrazone test. Analytical Chemistry 33, 9396.

Szent-Gyorgyi, A., Egyud, L. G. \& MCLaughuin J. A. (1967). Keto-aldehydes and cell division. Science 155, 539-541.

WARD, C. B. \& Glasser, D. A. (1969). Analysis of the chloramphenicol-sensitive and chloramphenicol-resistant steps in the initiation of DNA synthesis in $E$. coli $\mathrm{B} / \mathrm{r}$. Proceedings of the National Academy of Sciences of the United States of America 64, 905-912.

ZwaIG, N. \& Diegnez, E. (1970). A bactericidal product obtained from a mutant of Escherichia coli. Biochemical and Biophysical Research Communications 40, 1415-1422. 